\title{
Malaysia's Vision 2020 and the Role of leadership in Economic Development
}

\author{
Mahmoud Safy Mahmoud ${ }^{1} \&$ Hoda Mitkees ${ }^{1}$ \\ ${ }^{1}$ Faculty of Economics \& Political Sciences, Cairo University, Giza, Egypt \\ Correspondence: Mahmoud Safy Mahmoud, Researcher, Faculty of Economics \& Political Sciences, Cairo \\ University Cairo university, Giza, Egypt. E-mail: mahmoudsafy@feps.edu.eg
}

Received: April 16, 2017

doi:10.5539/ass.v13n8p49
Accepted: May 15, 2017 Online Published: July 25, 2017

URL: https://doi.org/10.5539/ass.v13n8p49

\begin{abstract}
Malaysia has adopted several developmental plans since 1969 starting with the New Economic Policy (NEP), passing by the National Development Plan (NDP) and ending with the Vision 2020 adopted in 1991 under the rule of Mahathir Mohammed (1981-2003), whereby Malaysia has aimed to become a developed country by 2020 . Looking for the future, Malaysia 2020 should build upon the older developmental plans; however there are some new elements that need to be considered if Malaysia is to continue on its successful developmental path. This paper aims at focusing on the issues that still need to be considered in Vision 2020 from an outsider point of view. This paper addresses the questions of what Malaysia's economic plans adopted in the past which were able to achieve high economic growth rates while preserving at the same time the social aspects. And the paper focuses on trade policy in Malaysia under Mahathir rule, identifying how was it shaped and how likely it will continue in 2020. The paper identifies the challenges likely to be faced by Malaysia in the coming period and how such issues should be tackled in Vision 2020.
\end{abstract}

Keywords: Economic development, Vision 2020, Development, leadership, Malaysia

\section{Introduction}

Malaysia had its independence in 1957. Its development plans including the economic ones have always tried to strike the social balance among its multi-ethnic population which consisted of Malays, Chinese, and Indians comprising $50 \%, 33 \%$, and $9 \%$ of the population respectively in addition to indigenous tribes. This was a counteraction to the inherited British policies which aimed at increasing the inequality among different ethnic groups, especially Chinese and Malays and finally led to the race-riots in 1969. The New Economic Policy (NEP) adopted by the Malaysian government focused on eradicating poverty and redistribution of wealth to bring parity among different ethnic groups. The government introduced in 1971 the first long-term development plan, called the First Outline Perspective Plan (OPPI) which has been extended for the period 1971-1990 and has been included under the context of NEP. The NEP can be described as an exercise in social engineering designed to reduce the socio-economic imbalances among different ethnic groups and between different geographical regions, in this context, Malaysia under Dr Mahathir Mohammad (1981-2003) has been described as independent, active and pragmatic. Two decades of Mahathir's leadership have resulted in Malaysia becoming more internationally recognized as a model of stable, multicultural and developing country with a relatively impressive economy. Our time span basically is 1981 till 2003 where we review the trends of economic development and trade policies in Malaysia under Mahathir Mohammad rule.

Malaysia has adopted a specific model of economic development where it has announced the motto of "growth with equity" as its ultimate goal. The different developmental plans and the accompanying five years plans have worked on serving this goal. Malaysia has not opted for the classical neo-liberal approach, but has developed its own version of capitalism where free market policies have been adopted while preserving the social aspects of the whole society. As a result, Malaysia was able to succeed. In fact the World Bank (2008) identified that Malaysia was among the best performing countries in the world and is a success story where it was able to increase its GDP per capita sixfold between 1967 and 2005 (rising from 790 US \$ to 4,400 US \$). The World Bank report identified the characteristics of the thirteen economies, among which was Malaysia, which were able to sustain high economic growth rates of $7 \%$ or more for more than 25 years. Among the characteristics were the following: full exploitation of the world economy; maintaining macroeconomic stability; applying market 
signals for allocating resources; and the presence of capable, committed, and credible governments. In fact, all such characteristics still apply in Malaysia as will be discussed below, among other issues which have shaped Malaysia success story in the past and should continue to shape its Vision 2020.

The paper starts in Section One by reviewing Malaysia's economic plans adopted in the past which were able to achieve high economic growth rates while preserving at the same time the social aspects. Section Two focuses on trade policy in Malaysia under Mahathir rule, identifying how was it shaped and how likely it will continue in 2020. In Section Three, the paper identifies the challenges likely to be faced by Malaysia in the coming period and how such issues should be tackled in Vision 2020. Finally the paper ends by a conclusion and lessons learned.

\section{Review of Past Economic Plans}

Trade policy has always been used as an engine for growth while maintaining social and equity goals, which represent an important pillar in the developmental strategy of Malaysia as reflected in the New Economic Policy (NEP) adopted in 1969 (and came into effect in 1970) which was later modified and renamed National Development Policy, or NDP, in 1990. The Vision 2020 represents the main developmental framework adopted by the Malaysian government, where social and ethnic aspects (mainly equity) represent the core element of such vision (McGinness, 2002). Hence, all other policies adopted within the vision consider significantly this social element.

Malaysia's economic and developmental plans have always considered the social and ethnic characteristics of Malaysia, paying specific attention to the income distribution between Malays (relatively poor), and the Chinese, and Indians (relatively richer). Since the introduction of the New Economic Policy (NEP) in 1969 Malaysia's government has always played an interventionist role in eradicating poverty, achieving equality in income distribution, and expanding opportunities for the "Bumiputra" or indigenous peoples (rural-based Malays and native ethnic groups of Sabah and Sarawak) in all sectors of the economy. NEP was launched in 1971 and focused on the socio-economic planning of the country. Its objectives included the reduction of poverty by increasing income levels, the maintenance of high sustainable growth, low unemployment rates and, ensuring the stability of economic factors such as inflation (Najera \& Santana, 2004). The NEP can be described as an exercise in social engineering designed to reduce the socio-economic imbalances among different ethnic groups and between different geographical regions (Abu-Bakar \& Hassan, 2003). The focus on "growth with equity" has continued where almost one third of government's total expenditure has been directed to social spending of all kinds aiming at eradicating poverty and upgrading human development aspects (with the exception of the period of treating the aftermath consequences of the financial crisis, where the government was under fiscal strain and refused to adopt the IMF austerity measures). The NEP has been appraised by commentators to have achieved its objectives (see for example, Abu Bakar, 2005).

Table 1. Sectoral Growth Performance: Contribution to GDP and Real Growth Rates (in bracket), 1970-1995*

\begin{tabular}{ccccccc}
\hline & 1970 & 1975 & 1980 & 1985 & 1990 & 1994 \\
\hline Agriculture & 28.5 & 26.9 & 22.9 & 20.8 & 18.7 & 13.9 \\
& $\ldots$. & $(9.5)$ & $(5.1)$ & $(3.1)$ & $(4.6)$ & $(2.5)$ \\
Industry & 32.3 & 32.6 & 35.8 & 36.7 & 42.2 & 47.2 \\
& $\ldots$. & $(6.7)$ & $(10.7)$ & $(5.7)$ & $(9.8)$ & $(11.2)$ \\
Manufacturing & 15.8 & 17.3 & 19.6 & 19.5 & 26.9 & 33.1 \\
Services & $\ldots$. & $(6.7)$ & $(11.4)$ & $(5.3)$ & $(13.7)$ & $(13.3)$ \\
& 33.5 & 40.5 & 41.3 & 42.6 & 39.1 & 38.9 \\
Total & $\ldots$ & $(12.2)$ & $(13.9)$ & $(5.8)$ & $(5.1)$ & $(8.6)$ \\
& 100 & 100 & 100 & 100 & 100 & $(8.9)$ \\
\hline
\end{tabular}

Note: * Output shares and growth rates are based on constant (1978) price data. Growth rates are annual averages between the reported years. Source: Athukorala, Prema-Chandra and Jayant Menon (1996)

The industrialization process has progressed in tandem with social objectives as it helped to enhance employment, fight unemployment, and raise income levels. This represents a major challenge for the Vision 2020 due to the intensive competition in the world market which can have negative impacts on achieving such social objectives. However, it is important to note that the major objectives of NEP have been social, and the means to achieve these social objectives were economic. For example, due to the high fiscal burden in the late 
1980s the Malaysian government opted for privatization and attraction of foreign direct investment (FDI) to be able to finance its developmental plans. Yet, such change of policies came with other economic costs represented in crony capitalism and high vulnerability to international macroeconomic fluctuations. Moreover, such policy created geographical disparities where some regions in Malaysia (mainly the rich) were able to attract foreign investments, which has not been the case of poor states (Abu Bakar \& Hassan, 2003). To continue achieving the social objectives of the NEP the Malaysian government started to depend more on community support programs rather than direct government intervention (McGinness, 2003).

The youth, the most important capital for Malaysia, was devoted special attention where a special National Youth Plan (NYP) which was an important part of the New Economic Policy (NEP) was formulated in 1985 and reviewed in 1997. The Youth Plan aimed at enhancing the knowledge of the youth, upgrading their skills, and advising them on healthy lifestyles, among other goals (Darusman, 2004). In other words, different aspects of social policy have been seriously considered in the NEP.

\subsection{The 1990s Onwards}

The twenty year period of NEP ended in 1990. A new program, the National Development Policy (NDP) replaced the NEP when it expired. The NDP maintained the basic policies of the NEP, based on the favorable experiences obtained in the past twenty years. The New Development Policy (NDP) was announced as a socioeconomic framework within which the Malaysian society should work for the next twenty years, 1991-2010. The NDP has as its main goal the "Vision 2020" program, by which Malaysia intends to become fully developed. It emphasized on science and technology and therefore, a further development of human resources, including a productive and disciplined work force to meet the challenges of an industrial society. The NDP represented an outgrowth of the NEP policies and it maintained the basic strategies of the NEP, but with a new dimension (Abu Bakar \& Hassan). The NDP emphasized mainly the adoption of an export led economy, and shifting the economy from being an inputs' driven economy to being productivity driven. (Ngiik \& Amin, 2006). In Vision 2020 the social aspect was also emphasized where one of the nine objectives for attaining developed country status is "a social system in which society will come before self, in which the welfare of the people will revolve not around the state or the individual but around a strong and resilient family system." (McGinness, 2003). Both NDP and Vision 2020 have built on the NEP however they have added new dimensions to cope with globalization including the need to attract foreign direct investment (FDI) and enhance technology transfer, shifting the emphasis from focusing on agriculture to manufacturing and from manufacturing of basic commodities to more sophisticated ones, etc (Najera \& Santana, 2006).

Malaysia's attempt to join the "information society" and "knowledge economy" by launching its ambitious Multimedia Super Corridor (MSC) was also mainly part of its realizing Vision 2020. Malaysia's multimedia super corridor is that country's unique way of joining the "information society" and assisting the transition to the "knowledge economy." The project was launched in 1996 and by 1999 it was up and running. It was realized soon thereafter that bringing Malaysian average income up to that of a "fully developed" state by 2020 — which was estimated to be about \$US10, 500 in (1994 dollars) could not be achieved by focusing mainly on significant increases in manufacturing (projected to grow by approximately 7\% per year and topping out at $38 \%$ of GDP in the mid-1990's (Huff, 2002).

To achieve its major economic and developmental plans as the NEP and NDP, the government introduced five year plans, each reflecting the urgent objectives of the major plans (NEP and NDP). For example, the First Malaysia Plan (1966-1970) was mainly concerned with population issues including health and education facilities. The Second Malaysia Plan (1971-1975) saw the formulation of the New Economic Policy (NEP). The Sixth Malaysia Plan (1991-1995) saw the emergence of the National Development Policy (NDP), which aimed to achieve national unity and balanced development as discussed above. The Seventh Malaysian Plan (1996-2000) tried to create skilled workers and stimulate a more technology-oriented culture to effect the structural transformation towards productivity driven economy. The Eighth Malaysian Plan (2001-2005) set out policies, strategies and programs to achieve the National Vision Policy's objective of building a resilient and competitive nation (Najera \& Santana, 2004). Hence, what we observe is a systematic type of planning, where the general plan involves five year plan, each focusing on the urgent aspect of the major plan. Vision 2020 emphasized that the rate of growth should be sustained at $7 \%$ year to be able to reach the goal of being a developed country by 2020. The NEP and NDP complemented by vision 2020 identified the means to achieve this high growth rate, namely via rapid industrialization through diversifying the manufacturing base and developing small and medium scale industries and inter industry linkages. In this context, development of human resources is of particular importance in meeting skills requirements of modern industrial economy. The different developmental plans ensured also the development of agriculture and services sectors to ensure a balanced 
growth formula. This type of planning should continue in the future, as it serves to put the major objectives and specify the important steps to be achieved.

Eradicating poverty was an integral element of all developmental plans. The strategy adopted to alleviate poverty included many aspects as those aiming to increase income and productivity for poor who suffer from low productivity occupations (by expanding productive capital and access to such capital); improving the living standards of the low-income groups by providing a wide range of free or subsidized social services as housing, electricity, water, transportation, health and medical services, education, recreation and community facilities; and increasing opportunities for inter-sectoral mobility from low productivity areas to high productivity areas. This was facilitated by the provision of financial and technical skills, necessary education and training and the organizational arrangements (Abhayaratne, 2001).

Table 2. Level of Poverty

\begin{tabular}{cccccccc}
\hline & \multicolumn{3}{l}{ National poverty line } & \multicolumn{3}{c}{ International poverty line } \\
\cline { 2 - 8 } & $\begin{array}{c}\text { Population below the } \\
\text { poverty line }\end{array}$ & & $\begin{array}{c}\text { Population } \\
\text { below \$1 a day }\end{array}$ & $\begin{array}{c}\text { Poverty gap } \\
\text { at \$1 a day }\end{array}$ & $\begin{array}{c}\text { Population } \\
\text { below \$2 a day }\end{array}$ & $\begin{array}{c}\text { Poverty gap } \\
\text { at \$2 a day }\end{array}$ \\
\cline { 2 - 8 } & $\begin{array}{c}\text { Survey } \\
\text { year }\end{array}$ & $\begin{array}{c}\text { National } \\
\%\end{array}$ & $\begin{array}{c}\text { Survey } \\
\text { year }\end{array}$ & $\%$ & $\%$ & $\%$ & $\%$ \\
Malaysia & 1989 & 15.5 & 1997 & $<2$ & $<0.5$ & 9.3 & 2 \\
Thailand & 1992 & 13.1 & 2002 & $<2$ & $<0.5$ & 25.2 & 6.2 \\
Indonesia & 1999 & 27.1 & 2002 & 7.5 & 0.9 & 52.4 & 15.7 \\
South Korea & N/A & N/A & 1998 & $<2$ & $<0.5$ & $<2$ & $<0.5$ \\
\hline
\end{tabular}

Source: World Development Indicators 2006 website, http://devdata.worldbank.org/wdi2006, last visited: 6/10/2006

While a number of improvements have been made to the original social policy formula in Malaysia, its core pillars have remained the same. These pillars have been: (a) emphasis on the development of social services as an integrated component of the national development agenda; (b) Government and public sector provision of social services; and (c) equitable provision of services to rural populations and to poor and low-income groups (ESCWA, 2005). Empirical evidence has shown that the main reason behind the success of Malaysia in achieving its developmental goals has been its focus as a central element of its developmental plans on poverty eradication and other social goals (Khan, 2002). This is in contrast to other countries where social policies and their improvement come as a by-product of the developmental plans.

\subsection{The social objectives of Malaysian economic plans}

The historical background of Malaysia shows that planning was a major aspect of Malaysia's development strategy where equity among ethnic groups and different geographical regions was at the core of this strategy. This aspect is of crucial importance as the success of Malaysia in managing globalization and its consequences is attributed mainly to its ability to handle the social element in a prudent manner. The neo classical conventional prescriptions of international organizations have focused mainly on the growth aspect and neglected till recently the social dimension which in many cases has led to backslides on reforms. Malaysia's development strategy, on the contrary, has put the social dimension at the core of its development strategy and has never thought of economic growth without including the social aspects as a predominant factor. While a number of improvements have been made to the original social policy formula in Malaysia, its core pillars have remained the same. These pillars have been: (a) emphasis on the development of social services as an integrated component of the national development agenda; (b) Government and public sector provision of social services; and (c) equitable provision of services to rural populations and to poor and low-income groups. (ESCWA, 2005)Empirical evidence has shown that the main reason behind the success of Malaysia in achieving its developmental goals has been its focus as a central element of its developmental plans on poverty eradication and other social goals. (Khan, Mahmood Hassan (2002). this is in contrast to other countries where social policies and their improvement come as a by product of the developmental plans.

\section{Trade and Industrial Polices: Review and Prospects}

An export oriented strategy has been adopted starting the mid 1970s (following the Third Five Year Plan 1976-1980) which fuelled Malaysia's growth rates and enhanced its integration in the world economy. Its trade openness measure (exports + imports divided by GDP) has increased dramatically from $75.25 \%$ in 1990 to 
93.55\% in 1997 which was translated into a buoyant economic growth as Malaysia grew at about $8 \%$ during the 1987-1997 period spearheaded by the exports of manufactures (Abu-Bakar \& Hassan, 2003). The high growth rates continued after Malaysia recovered from the 1997 financial crisis and its integration in the world economy continued to increase where trade openness indicator reached 145\% of GDP in 2009 (World Bank, 2011). Climbing up the ladder of value added was one of the main objectives of the strategy of development in Malaysia where moving from primary goods to more sophisticated goods where Malaysia can compete was among the most important economic aims. In the 1970s and early 1980s, Malaysian economic growth was predominantly accounted for by the expansion of service industries emanating from public sector activities and growth in primary production.

In addition Malaysian government adopted an aggressive industrial policy which intensified in the 1980s. For example, the Heavy Industries Corporation of Malaysia (HICOM), a public sector holding company, was formed in 1980 to go into partnership with foreign companies in setting up industries in areas such as petrochemicals; iron and steel; cement; paper and paper products; machinery and equipment; general engineering; transport equipment; and building materials. The symbol of the selective industrial policy was the Proton (the Malaysian national car) project, a joint venture of HICOM and Mitsubishi Corporation in Japan. The number of corporate public enterprises in Malaysia has been on a rising trend with a special focus on manufacturing where in the 1980s more than a third of which were in manufacturing. The use of industrial policy with some protection features was evident also in Malaysia's response to the 1997 crisis where applied tariffs were increased on a number of goods as well as imposition of import licensing scheme. This implies that Malaysian government despite the adoption of a liberal trade policy was never hesitant to introduce protectionist measures whenever they were needed to achieve certain social goals (as preservation of employment) and/or economic goals (as releasing the pressure on balance of payments).

The manufacturing sector is currently the second largest contributor to the nation's economic growth, with electronics taking the lead in the sector's expansion. For example, in terms of technology and knowledge, today, Malaysia is the exporter of most of the world's Dell laptop computers and Intel high-end processors. Some examples of measures implemented are the establishment of a New Technology Investment Fund in 2001 with an initial capital of RM500 million to attain equity in foreign companies. Another measure has been the provision of matching grants for firms in selected sectors to undertake research and development (R \& D) activities for the purpose of rental of facilities in science and technology parks R \& D costs, including R \& D projects jointly undertaken by industry and research institutions, universities or research-based firms will also be matched by the Government (Leigh \& Lip, 2001). Manufacturing and services now make up over $80 \%$ of GDP, and manufacturing's share of total exports has increased from $22 \%$ in 1980 to $85 \%$ in 2000 . The transformation of Malaysia's export structure in line with emerging patterns of the international division of labor gathered momentum only in the late 1980s; by the 1990s, the share of resource-based exports had declined while the shares of electronics, electrical machinery and appliances rose sharply. As a result of this rapid export expansion, the share of exports in gross manufacturing output was over $60 \%$ in the early 2000 s, compared to less than $10 \%$ in the early 1970s (Athukorala \& Menon 1996). For example, despite the relatively low average tariff level applied by the Malaysian government there has always been tariff peaks on specific products as automobiles textiles, and clothing. In addition, the Malaysian government has used export subsidies to promote specific sectors.

In general the government has focused its efforts in terms of subsidies and protection on manufactured goods, signaling a bias towards industrialization (Athukorala, 2005). The bias towards manufacturing and industrialization might have boosted Malaysia's economic growth but has made it vulnerable, as well as other factors as pegging the exchange rate to US dollars, to business cycles in the developed world (WTO, 2005).

Malaysian government has a relatively liberal trade policy in the field of agriculture, yet it continuous to apply production subsidies schemes for certain products. The services sector in Malaysia is open for foreigners however with restrictions on foreign ownership and foreigners' accession to a number of professional services. The vulnerability to business cycles has shifted the trade and industrial policy in Malaysia towards devoting more efforts to agriculture and services. Malaysia has made commitments in 73 subsectors of the GATS which is considered high.

The Malaysian government has always tried to ensure a strong link between technology and industry. In 1986, the government launched the National Science and Technology Policy aiming at providing a broad framework for science, engineering and technology development. The government always emphasized industrial deepening aiming at enhancing technological capability of specific industries, which has been achieved by undertaking complex and demanding tasks including the development of new processes and systems, adaptation of best 
practices, and innovation. Moreover, the government has worked on enhancing the link between universities, research institutions and industries through different programs (Ali, 2005).

Malaysia's membership in the GATT dates back to 1957, and automatically has been a member of WTO which was established in 1995. Malaysia has been always trying to get its policies in line with GATT/WTO rules and obligation. Malaysia, as argued above, has always supported a free trade regime, which was also signaled in its positions in the GATT and WTO especially during the Uruguay Round (1986-1994). Yet such position has dwindled in light of the 1990s financial crisis and the formal position has adopted a more cautious approach in liberalization, which is a position that has been adopted by several developing countries in the wake of Uruguay Round (Athukorala, 2005). Malaysia has bound its tariff rates at $24.5 \%$ on average whereas its applied rate in 2007 was on average $8.4 \%$ and in the case of agriculture it has a bound rate of $76 \%$ with an applied rate of $11.7 \%$ (WTO, 2005).

The opening up of the Malaysian economy and adopting an export oriented strategy was not undertaken in ad hoc manner and without ensuring that safeguard options for temporary protection measures can be imposed. For example, Malaysia despite its enthusiasm for opening up within the regional context of the ASEAN free trade area agreed upon in 1993 among ASEAN leaders has imposed several protectionist measures on the car industry. The main reason is protecting its car manufacturing infant industry as Proton and Perodua which it felt it still not ready to stand up for regional competition (Chirathivat \& Murshed, 2001).

In fact, ASEAN was initiated in 1967 by Indonesia, Malaysia, the Philippines, Singapore, and Thailand as a non-communist arrangement to promote economic, social, and cultural cooperation and development among its members, and to resolve regional disputes and reduce the opportunities for big power interventions in Southeast Asia. As security related issues gained less importance, ASEAN turned more explicitly to issues of trade, stabilization of commodity prices, market openings, and effort to attract development assistance from industrialized countries. Deep economic relations started to develop starting the 1970s and developed dramatically in the 1980s due to the huge inflows of investments from Japan and South Korea in the region. By the mid 1990s East Asia became one of the most integrated regions in the world through intra regional trade and investment. The pattern of trade and investment became more complicated involving multiple sources, increasing complementarily, high degree of independent corporate and market driven decision making, and webs of overlaps and interconnections (Pempel, 1999b). In other words, the regional integration of Malaysia started with developmental aims and at its inception had less focus on trade integration per se. By time, trade aspects started to gain more importance in Malaysia as well as other regional neighbors.

As seen from the above review Malaysia foreign trade position has always been using trade as an engine to achieve other goals which implied that its adherence to open trade regime was always interrupted when needed to reach other goals. Moreover, there have been major changes in Malaysia foreign trade policy where a more protectionist attitude or rather a cautious liberalization approach has been adopted as time passed, and a shift towards regionalism can be as well observed.

Table 3. Government Expenditures Comparison (1995/2004)

\begin{tabular}{|c|c|c|c|c|c|c|c|c|c|c|c|c|}
\hline & \multicolumn{2}{|c|}{$\begin{array}{l}\text { Goods and } \\
\text { services }\end{array}$} & \multicolumn{2}{|c|}{$\begin{array}{l}\text { Compensation } \\
\text { of employees }\end{array}$} & \multicolumn{2}{|c|}{$\begin{array}{c}\text { Interest } \\
\text { payments }\end{array}$} & \multicolumn{2}{|c|}{$\begin{array}{c}\text { Subsidies, grants, } \\
\text { and other social } \\
\text { benefits }\end{array}$} & \multicolumn{2}{|c|}{$\begin{array}{c}\text { Other } \\
\text { expenditure }\end{array}$} & \multicolumn{2}{|c|}{ Expense } \\
\hline & \multicolumn{2}{|c|}{$\%$ of expense } & \multicolumn{2}{|c|}{$\%$ of expense } & \multicolumn{2}{|c|}{$\%$ of expense } & \multicolumn{2}{|c|}{$\%$ of expense } & \multicolumn{2}{|c|}{$\%$ of expense } & \multicolumn{2}{|c|}{$\%$ of GDP } \\
\hline & 1995 & 2004 & 1995 & 2004 & 1995 & 2004 & 1995 & 2004 & 1995 & 2004 & 1995 & 2004 \\
\hline Indonesia & 21 & 8 & 20 & 13 & 16 & 16 & 41 & 63 & 2 & 0 & 9.7 & 16.8 \\
\hline Malaysia & 23 & 26 & 34 & 30 & 17 & 12 & 27 & 31 & 1 & 1 & 17.2 & 20.1 \\
\hline Thailand & N/A & 21 & N/A & 32 & N/A & 8 & N/A & 33 & $\mathrm{~N} / \mathrm{A}$ & 7 & N/A & 19.6 \\
\hline South Korea & 16 & 12 & 15 & 11 & 3 & 6 & 63 & 56 & 3 & 15 & 14.3 & 18.6 \\
\hline
\end{tabular}

Source: World Development Indicators 2006 website, http://devdata.worldbank.org/wdi2006/contents/Section4.htm, last visited: 6/10/2008

\section{Prospects for Vision 2020}

Malaysia is likely to continue with its home grown version of capitalism in 2020. Capitalism is a country based phenomenon and not a western or an American phenomenon implying that Malaysia, as well, as other Asian countries are likely to have their own version of capitalism. Malaysia's consideration of aspects considered when dealing with the 1997 crisis is likely to prevail in the future. Political national sovereignty shaped by specific 
cultural and social characteristics represents a major aspect of Malaysia's economic policies in general and trade and industrial policy in specific. In this regard Malaysian capitalism is presumed to rest on market institutions that are objective and pays great attention to society and culture. Hence, the socio economic aspects of Malays and Chinese are likely to be reflected on how capitalism is likely to be approached by Malaysia in 2020. The most important aspect is that capitalism, whether the Malaysian way or any other way includes the incentive structures that are correctly constructed and strictly and fairly enforced (Hamilton, 1999). In this regard, it is worth mentioning that the export led growth model that Malaysia has adopted for a long while cannot be the main pattern of development for Malaysia in 2020. The global imbalances and the 2008 financial crisis identified clearly that the export led model cannot be maintained.

Moreover, there are several elements that need to be taken into consideration if we are to plan for Malaysia 2020.

Firstly, we cannot lump up Malaysia with other Asian countries, or at least the Asian tigers. There is no one size that fits all and in fact empirical evidence, has shown us that Malaysia acted differently in combating the 1997 financial crisis, partially due to its domestic politics impact on economics.

Secondly, the role of the state in the economy will always remain substantial and ready when there is a need. With deregulation and liberalization, the state might need to interfere aggressively to save the economy, whereas its role will diminish when re-regulation takes place.

Thirdly, and much related to the first point, is that domestic politics play a great deal of influence in shaping Malaysia 2020. The special element of the status of Malays and Chinese, and the socio-economic status is likely to affect any strategy in the future, as has been the case in the past. Yet, although domestic politics may play the dominant role in government policy responses to the economic crisis, Vision 2020 is likely to show that such responses need to be tempered by the need to consider the views of foreign and local capital market actors, because their capital is needed for recovery to occur more swiftly.

Fourthly, economic aspects in general of Malaysia 2020 is likely to be determined by a collective economic strategy that plays crucial importance to the role of politics on the national, regional, and international levels. On the international front, Malaysia 2020 should be paying great attention to the geopolitics changes and shifts of power (economic and political) from the US to the BRIC, and especially China. Moreover, the reemergence of global finance on a huge scale, in combination with the late twentieth century technology and communications, is a volatile mix that must be counted for by Malaysia especially after experiencing the negative effect of the 1997 and 2008 financial crisis.

Fifthly, Malaysia has always focused on a specific sector (manufacturing and then knowledge economy) as a mean to achieve its developmental goals. It is likely that Malaysia will shift to new sectors as nano-technology and other new technologies to reach its Vision 2020.

Finally, on the regional level, the silent, but deep integration taking place between Malaysia and its neighbors is likely to continue. Also Malaysia's long term attractiveness as a financial and business center in the region still depends on its neighbours' economic recovery and its own political relations with them.

There are a number of challenges that should be paid specific attention in any future economic and development planning including the following:

- Regional disparity should be paid greater attention by policy makers. Despite that efforts have been undertaken to deal with such challenge, yet they remain short due to increasing capital inflows directed to specific regions.

- Ethnic disparity in terms of incidence of poverty is also among major challenges that persist facing Malaysia. Despite the fact that tremendous efforts have been undertaken to lower the incidence of poverty including overcoming the ethnic disparity (e.g. devoting special quotas for the Malays' school enrollment), the ethic dimension still remains urgent with the highest poverty incidence concentrated among the Malays.

Malaysia has always believed in the role of a strong interventionist government aiming mainly at ensuring social equity for all its citizens' races and classes. This has been evident from its economic plans adopted since the 1960s.

- Starting the 1980s Malaysia started adopting liberal economy type of policies, export oriented strategy. However, such polices which included as well lessening the role of the government in the economic life in general were undertaken in a planned sequenced pace, while minimizing the role in the social affairs with a slower pace than other activities. For example out of the operating budget the expenditure on social affairs was reduced only from around $33 \%$ in 1997 to $29.5 \%$ after the crisis in 1998. Moreover, the government introduced temporary safety net programs and maintained its original 1998 budget allocation of the Development Program for the Hardcore Poor and limited cuts in spending for social, rural development and agriculture programs 
targeting the poor and low-income groups. Spending toward health and education was also maintained. Hence, Malaysia was able to prevent deep social insecurity. However, and despite such generous social programs the Malaysian government has always resisted introducing formal programs for the unemployed believing that this will result in negative repercussions and will encourage unemployment.

- Immigration is another challenge that requires specific attention. Past immigration policies have helped to maintain a stable environment for nationals and immigrants who constitute around $8-10 \%$ of the population. Yet, due to the continuing economic growth achieved in Malaysia immigrants are likely to increase. Issues affecting ethnicity and cultural pluralism, decent work, and skilled labor force should be considered in this Vision. So far, Malaysia has adopted an effective immigration policy that has helped her to undertake the economic growth without any negative social considerations. Yet, with the increased migration of Chinese all over the world, the different composition of the population might be altered, which could have significant impact on ethnicity and social policies. Despite Malaysia has been described to have an effective immigration and foreign labor management policies, the problem of informal labor market for foreign immigrants has been increasing due to restrictive immigration measures and high work permit fees (Ruppert, 2002). Moreover, the influx of immigrants has created social problems associated with crimes, slumps, and illegal settlements (ESCWA, 2005). Also, if Malaysia continues to develop faster than its neighbors this could have an extreme pressure on its immigration status as it will be more attractive. On the other hand, and with high growth rates achieved, there is a need for different types of foreign labor which will result in pressures on the formal labor market. All such issues of immigration represent a major challenge that need to be tackled in Vision 2020.

- The Malaysian social policy has resulted in improvements in education, health and medical care and has ensured greater employment opportunities and a higher level of social protection for all people. Furthermore, it has made significant impact on the eradication of poverty and has boosted the women and youth participation in the national development process (ESCWA, 2005). Keeping such social policy efficient and moving to a welfare state is also among the challenges that face Malaysia. The existing safety net adopted, in terms of the Employees Provident Fund (EPF) for private sector employees and the Government Pension Scheme for public sector employees has been working relatively well. Moreover, under the government pension scheme, public sector employees upon retirement are entitled to one-third of their last salary for as long as they live ${ }^{1}$ (Ariff \& Abubakr, 2003). However, there is still no mandatory schemes for the self-employed, including entrepreneurs, which with the changes of the economy might need to be institutionalized.

- Finally, Johnson et. al, 2006 show that the benefits accrued by the politically backed up firms (often identified as the feature of crony capitalism) have declined significantly in the aftermath of the crisis. Surely prudent financial regulations adopted by the Malaysian government and its financial sector have helped to lessen the negative influence of politically backed up businessmen. However, it is worth mentioning that Malaysia still suffer from a number of loopholes in its governance, judicial, and legal system. There is a lack of judicial autonomy, in addition to other issues that need to be considered to strengthen the institutional infrastructure (Yusuf, 2001).

\section{Conclusion and Lessons Learned:}

Malaysia has proven to apply capitalism in its own version which brought fruitful results, not only on the economic front, but as well on the social front. The blending of social and economic aspects in every economic decision has kept "growth with equity" enact. In fact, Malaysia was able to identify what economic development theorists have emphasized that should be included in the new generation of economic models as social capability, culture, role of technology, and complementarily of market and state( Meier, 2001). The trade and industrial policies adopted have been used to achieve social goals and ensure long sustainable economic gains. All such sources of success should be continued in the future and emphasized in Vision 2020. However, challenges still remain and are likely to increase with the high growth rates and impressive developmental efforts. Vision 2020 should be able to address such challenges while keeping "growth with equity" as the main goal.

Malaysia under the leadership of the country's fourth Prime Minister, Mahathir Mohammad (1981-2003). (Saravanamuttu, 1980) has left an almost inimitable legacy in Malaysia's economic development arena. In addition to the domestic considerations, Malaysia's external conduct was very much influenced by the strong personality of Mahathir. There is no doubt that Malaysia had benefited tremendously from its active participation

\footnotetext{
${ }^{1}$ The EPF guidelines state that all employees must contribute 11 percent of their monthly salary, and employers 12 percent of the employee's monthly salary, to an EPF account set up on behalf of the employee. The money is then invested on behalf of the employee, and this forms the bulk of the employee's retirement fund.
} 
and growing prominence in the international arena during more than 20 years of Mahathir's leadership.

The main lesson learned from the Malaysian experience especially under Mahathir Mohammad rule. Is that market forces should have a predominant role; however it should be complemented by an active interventionist government's policy that is able to mitigate market failures and ensure social justice.

Coping with globalization does not always imply dismantling of the state's role through liberalization, deregulation, or privatization. In many cases coping with globalization requires a strong intervention through re-regulation especially when a country suffers from institutional deficits and is in bad need of government's intervention to upgrade its institutional setup.

The other main lesson learned is that countries should aim to attract foreign direct investment not only and solely for filling the saving-investment gap, but also for absorbing new technologies, which has the main aim by Malaysia and other East Asian countries.

The Malaysian experience has shown that rapid economic growth plays an important role in this respect; it alone cannot guarantee social harmony. Therefore, the formulation of social policy must be integrated into the overall development agenda. However, any country emulating the Malaysian experience has to take into consideration its own specific characteristics to be able to draw the right vision and implement the required policies accordingly.

Malaysia provides an excellent example of a country that was able to effectively manage globalization, rather than globalization guiding Malaysia's economy. The pace and the method of opening up to the global economy provide an excellent example of how a country can turn the challenges of globalization to its benefit. (Prakash, 2001), the key to success lies in the planning and vision that Malaysia had while not only focusing on achieving high economic growth rates, but ensuring as well social stability and income equality.

Finally, the Malaysian experience points out that social challenges are of paramount importance if the aim is sustainable development. Putting social aims at the core of any developmental strategy ensures two main aspects, namely, that economic growth can be achieved with equity, and that sustainable development cannot be achieved while neglecting social concerns.

\section{References}

Abhayarante, A. (2001). Poverty Reduction Strategies in Malaysia 1970-2000: Some Lessons. Department of Economics and Statistics, University of Peradeniya, Sri Lanka, Retrieved from www.cassey.com/FEA2004-14.pdf.

Abu-Bakar, N. A. (2005). Growth and Development Policies in Malaysia. Faculty of Economics, Universiti Utara Malaysia, Retrieved from www.decon.unipd.it/aispe/assets/pdf/abstracts/abs_abubakar.pdf.

Abu-Bakar, N. A., \& Hassan, A. A. G. (2003). Globalization and Inequality: The case of Malaysia. Paper presented at the UNU/WIDER Conference on Sharing Global Prosperity, held at Helsinki, Finland, 6-7 September, 2003.

Ali, A. (2005). Engaging Economic Development through the Commercialisation of Research: The Malaysian Experience. Mimeo.

Athukorala \& Menon. ( 1996). Foreign Investment and Industrialization in Malaysia: Exports, Employment, and Spillovers. Asian Economic Journal, 10(1). Retrieved from http://onlinelibrary.wiley.com/doi/10.1111/j.1467-8381.1996.tb00156.x/epdf.

Athukorala, P.-c. (2005). Trade policy in Malaysia: liberalization process, structure of protection, and reform agenda. ASEAN Economic Bulletin. Retrieved from https://www.researchgate.net/publication/236707805 Trade_Policy_in_Malaysia_Liberalization_Process_Structure_of_Protection_and_Reform_Agenda

Chirathivat, S., \& Mansoob Murshed, S. (2001). Globalization and Openness: Lessons from Recent Crisis in South East Asia. United Nations University WIDER, Discussion Paper No. 2001/35.

Darusman, M. S. (2004). Country Report by Malaysia. Paper presented at the Ministry of Human Resources, Malaysia.

Economic and Social Commission for Western Asia (ESCWA). (2005). Social Policies in Malaysia. Social Policy Series No. 4, United Nations.

Hamilton, G. (1999). Asian Business Networks in Transition. In T. J. Pempel (Ed.), The Politics of The Asian Economic Crisis. Itahaca and London: Cornell University. 
Huff, T. E. (2002). Malaysia's Multimedia Super Corridor and Its First Crisis of Confidence. Asian Journal of Social Science, 30(2), 248-270.

Johnson, S., Kochhar, K., Mitton, T., \& Tamirisa, N. (2006). Malaysian Capital Controls: Macroeconomics and Institutions. IMF Working Paper No. WP/06/51.

Kaplan, E., \& Rodrik, D. (2001). Did The Malaysian Capital Controls Work?

Khan, M. H. (2002). When is Economic Growth Pro Poor? Experiences in Malaysia and Pakistan. IMF Working Paper No. WP/02/85. Washington D.C.: IMF.

Leigh, M., \& Lip, B. (2001). Transitions in Malaysian Society and Politics: Towards Centralizing Power. Chapter 18 in Michael Leigh and Belinda Lip Transitions in Malaysia.

McGinness, A. (2002). The Human Face of the Asian Financial Crisis in Malaysia and Indonesia. In Swords and $\begin{array}{lllll}\text { Ploughshares, } & 8(1), & \text { spring } & \text { 2003. } & \text { Retrieved }\end{array}$ www.american.edu/academic.depts/sis/students/sword/Back_Issues/4.pdf

Meier, G. M. (2001). The Old Generation of Development Economists and the New. In G. Meier, \& J. Stiglitz (Eds.), Frontiers of Development Economics. (Washington D.C.: Oxford University Press and the World Bank).

Mohamed, A., \& Abubakar, S. Y. (2003). Strengthening Entrepreneurship in Malaysia. Mimeo.

Ngiik, A. W. M., \& Amin, N. (2006). Globalization: Enhancing Competitiveness of the Small and Medium Industries Through Productivity Growth: The Case of Sarwak, Malaysia. MARA University of Technology.

Pempel, T. J. (1999b). Regional Ups-Regional Downs. In T. J. Pempel (Ed.), The Politics of The Asian Economic Crisis. Itahaca and London: Cornell University.

Prakash, A. (2001). The East Asian crisis and the globalization discourse. Review of International Political Economy, 8(1), 119-146.

Ruppert, E. (2002). Managing Foreign Labor in Singapore and Malaysia: Are There Lessons for GCC Countries?. World Bank, mimeo.

Saravanamuttu, J. (1980). Malaysia's Foreign Policy 1957-1980; and (1997); and 'ASEAN in Malaysian Foreign Policy Discourse and Practice (1967-1997). Asian Journal of Political Science, 5(1). See also Camroux, D. (1994). "'Looking East' ... Inwards: Internal Factors in Malaysian Foreign Relations during the Mahathir Era, 1981-1994," Papers No. 72, Griffith University Centre for the Study of Australia-Asia Relations-Australia-Asia.

World Bank. (2008). The Growth Report: Strategies for Sustained Growth and Inclusive Development, A report by the Commission on Growth and Development.

World Bank. (2011). Data Catalogue. Retrieved from http://data.worldbank.org/indicator

World Trade Organization. (2005). Trade Policy Review for Malaysia. WT/TPR/S/156, 12 December 2005.

Yusuf, S. (2001). The East Asian Miracle at the Millennium. In J. Stiglitz \& S. Yusuf (Eds.), Rethinking The East Asian Miracle. A co-publication of the World Bank and Oxford University Press.

\section{Copyrights}

Copyright for this article is retained by the author(s), with first publication rights granted to the journal.

This is an open-access article distributed under the terms and conditions of the Creative Commons Attribution license (http://creativecommons.org/licenses/by/4.0/). 